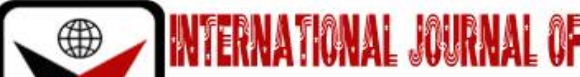

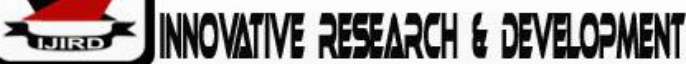

ISSN 2278 - 0211 (Online)

\section{Prevalence of Sorbitol-Negative Escherichia coli 0157:H7 Strain in Beef and Cattle Faeces in Jos South L.G.A Plateau State Nigeria}

Dayok Olukemi
Lecturer, Department of Science, Plateau State Polytechnich Barkin Ladi, Nigeria
Kum Folakemi Olushola
Zang Bright Nyam
Lecturer, Department of Science Department, Plateau State Polytechnich Barkin Ladi, Nigeria
Lecturer, Department of Science Department, Plateau State Polytechnich Barkin Ladi, Nigeria

\begin{abstract}
:
This research work was aimed at determining the prevalence of sorbitol-negative Escherichia coli 0157:H7 strain in beef and cattle faeces in Jos South L.G.A Plateau state, A total of two hundred samples from beef and cattle faeces were collected. The samples were subjected to bacteriological analysis with one gram (1g) of each sample (beef and faeces) homogenized and inoculated into a prepared try tone soya broth and peptone water respectively and incubated at 3 $7^{\circ} \mathrm{C}$ for 24hours for pre-enrichment. After which $0.1 \mathrm{ml}$ of the overnight culture was inoculated on a prepared MacConkey agar and later sub-cultured onto cefixime tellurite Sorbitol MacConkey agar and incubated at $37^{\circ} \mathrm{C}$ for 24hours for isolation of E. coli and E. coli 0157:H7 strains respectively. The result of this shows that out of the 200 samples cultured and analyzed, the overall prevalence of E. coli 0157. H7 was 13 (10.83\%). Infection rates of 8 (10.8\%) were observed in the meat sample which is higher compared to 5 (10.87\%) from the faecal samples. There was no significant difference between the two sample's type ( $p>0.05)$. The male subjects had higher prevalence rate ofE. coli 0157:H7,11(8.8\%) in both samples which is higher than that of the female 2(2.27\%) with a significant difference between them $(p<0.05)$. The most significant finding from this study is the isolation of E coli 0157 . 7 from our food product sold in the market which has economic implication of health risk on the general public. These results are indication of the poor sanitary environment under which the animals are slaughtered and processed. Hence application of good hygiene practices in the abattoir, good animal husbandry, pre-skinning decontamination as well as incorporation of Hazard Analysis and Critical Control Points (HACCP) in the abattoir is recommended.
\end{abstract}

Keywords: E. coli, E coli 0157:H7, beef, faecal samples, cattle, abattoir

\section{Introduction}

Escherichiacoli is a wide spread intestinal commensal organism found in human and animal resulting from faecal contamination during food animal slaughter; it is often found in soil, water and foods. Domestic and wild animals are the major sources of entero-haemorrhagic Esherichiacoli (EHEC) 0157:H7 (Ferens and Hovde, 2011), but the major animal carriers are healthy domesticated ruminants, primarily cattle (Gyles, 2007).

Contamination of meat with faecal material in the slaughtering process is the main transmission route of E.coli0157:H7 (Islam et al., 2008).

The first outbreak in 1982, E.coli 0157:H7 has become the widely known strain. Reports have shown that an E.coli 0157:H7 strain that was involved in an Outbreak of haemorrhagic colitis in the United States produced Shiga toxins. Shiga toxin E. coli (STEC) was epidemiological associated with haemolyticuraemic Syndrome (Bell, 2002).

Reported outbreaks have been linked to contaminated drinking water and irrigation with water contaminated by animal faeces, discharges from sewage treatment facilities or surface run off (Solomon et al., 2002).

Generally, E. coli can be a member of the normal micro-flora in animals including human. However, virulence genes acquired through various ways in the ecosystem enabled $E$. coli to acquire different forms of genes that lead to increased pathogenicity (Akanbi et al., 2011).

Shiga toxin producing E. coli (STEC) 0157 has emerged as public health threat. It colonizes the gastrointestinal tract and is associated with a range of symptoms which includes watering or bloody diarrhea, vomiting, haemorrhagic colitis and haemolyticuraemic syndrome, which are characterized by acute renal failure affecting mainly children and the immune compromised persons (Griffin and Tauxe, 1991; Akanbi et al., 2011). 
A significant number of infected persons suffer a range of permanent disabilities, including chronic renal insufficiency hypertension defects (Tarr et al., 1995).

Escherichia coli 0157.H7 has been transmitted through several routes including beef products such as ground beef, roasted beef, and dairy products such as. raw milk, cheese, butter (Range et al., 2005).

In spite of the wide knowledge of the organism and its interaction, there seem to be limited information regarding the prevalence of E. coli 0157:H7 in ruminant meat in Africa and particularly Nigeria, especially north central Nigeria, despite its major involvement in livestock rearing. Most of the livestock are reared in the north which is mainly a savanna region, and almost all the animals in the south that are slaughtered originate from the north. In the light of these prevailing circumstances, and the increased reported cases of E. coli 0157 infection outbreak worldwide (Center for Disease Control, 2002), it becomes apparent for this part of the country to ascertain its presence in our food products. Therefore, this study is aimed at determining the prevalence of sorbitol-negative E.coli 0157:H7 strain in raw beef, from Jos abattoir and in cattle faeces in Jos South L.G.A, Plateau State, Nigeria.

\section{Materials and Methods}

\subsection{Study Location}

This research was conducted at Jos abbatoir and Jos-South LGA of Plateau State, Nigeria.

\subsection{Sample Size}

A total number of 200 samples were collected (100 raw beef and 100 faecal sample from cattle), using simple random sampling technique (Yates et al., 2008).

\subsubsection{Sample Collection}

Hundred (100) samples each of fresh beef from abattoir and freshly voided faeces from life cattle in Livestock investigation division (LID), Vom were skeptically collected using the method adopted by Olatoye, (2010) in sterile sample bags and was immediately transported to the Laboratory for analysis.

\subsubsection{Preparation of Media}

All the media were prepared aseptically and in accordance with the manufacturer instruction.

The media were autoclaved at $121^{\circ} \mathrm{C}$ for 15 minutes and in molten state it was poured aseptically into sterile plates and allowed to solidify. The plates were incubated at $37^{\circ} \mathrm{C}$ for 24 hours to ensure sterility of the media and guard against contamination which may affect the result.

\subsubsection{Isolation of E. coli}

Each of the samples was homogenized and $1 \mathrm{~g}$ of the homogenate sample was suspended in $9 \mathrm{ml}$ of the prepared, tryptonesoya broth and incubated at $37^{\circ} \mathrm{C}$ for 24 hours. After which $0.1 \mathrm{ml}$ of mixture was spread on the MacConkey agarplate and Incubated for 24 hours at $37^{\circ} \mathrm{C}$. Isolates or colonies with pink to red colors (lactose fermenters) were picked and characterized using standard biochemical test, to confirm E. coli.

\subsubsection{Identification ofE. Coli 0157:H7}

Pure cultures of positive E. coli were cultured on cefixime tellurite Sorbitol-MacConkey (CT-SMAC) agar using the recommended method of Veriozy-rozand (1997) and incubated at $37^{\circ} \mathrm{C}$ for 24 hours.

\subsubsection{Gram Staining}

Each colony was picked and stained using the Gram's reagent and viewed under the microscope. This was done to easily differentiate between the Gram positive and Gram-negative bacteria and to note their shapes and structures. Escherichia coli is a gram negative bacteria.

\subsubsection{Biochemical Tests}

Biochemical tests were carried out on the test organism to identify them as described by Cheesbrough, (1991), there are catalase, indole, citrate utilization, urease and oxidase test were biochemical test carried out on the test organism to identify them (Cheesbrough, 1991).

\section{Results}

\begin{tabular}{|c|c|c|c|}
\hline Sex & No. of Sample & $\begin{array}{c}\text { No. of Positive Sample } \\
\text { E.coli (\%) }\end{array}$ & $\begin{array}{c}\text { No. of Positive sample } \\
\text { E.coli 0157:H7(\%) }\end{array}$ \\
\hline Male & 70 & $59(84.28)$ & $7(11.86 \%)$ \\
Female & 30 & $15(50.00)$ & $8(10.83 \%)$ \\
\hline Total & 100 & $74(74 \%)$ & $8(10.83 \%)$ \\
\hline
\end{tabular}

Table 1: Prevalence of Escherichia Coli and E.Coli 0157:H7 in Beef Based on Sex of Cattle $X^{2}=11.11 \quad$ OR $=0.1864 \quad P$ Value $=0.003 \quad P<0.05$ 
The male subjects recorded the highest prevalence rate of $59(84.28 \%)$ of E.coli and 7(11.86\%) of E.coli0157:H7. While the female has 15(50.00\%) of E.coli and 1(6.67\%) of E.coli 0157:H7. There is a significant difference between the sex of the cattle $(\mathrm{P}<0.05)$.

\begin{tabular}{|c|c|c|c|}
\hline Sex & No. of Sample & $\begin{array}{c}\text { No. of Positive Sample } \\
\text { E.coli (\%) }\end{array}$ & $\begin{array}{c}\text { No. of Positive sample } \\
\text { E.coli 0157:H7(\%) }\end{array}$ \\
\hline Male & 45 & $33(73.3)$ & $4(12.12)$ \\
Female & 55 & $13(23.6)$ & $1(7.69)$ \\
\hline Total & 100 & $46(46 \%)$ & $5(10.86 \%)$ \\
\hline
\end{tabular}

Stable 2: Prevalence of Escherichia Coli and E.Coli 0157:H7 in Cattle Faeces Based on Sex of Cattle

$X^{2}=8.44 \quad$ OR $=3.692$ P Value $=0.001 P<0.05$

The male subjects recorded the highest prevalence rate of 33(60.00\%) of E.coli and 4(12.12\%) of E.coli 0157:H7. While the female has $13(28.89 \%)$ of E.coli and $1(7.69 \%)$ of E.coli 0157:H7. There is a significant difference between the sex of the cattle $(\mathrm{P}<0.05)$.

\begin{tabular}{|c|c|c|c|}
\hline Sample Source & No. of Sample & $\begin{array}{c}\text { No. of Positive Sample } \\
\text { E.coli (\%) }\end{array}$ & $\begin{array}{c}\text { No. of Positive sample } \\
\text { E.coli 0157:H7(\%) }\end{array}$ \\
\hline Fresh Meat (Jos Abbatoir) & 100 & $74(74 \%)$ & $8(10.81 \%)$ \\
Faecal Sample (NVRI, Vom) & 100 & $46(46 \%)$ & $5(10.87 \%)$ \\
\hline Total & 200 & $120(60 \%)$ & $13(10.83 \%)$ \\
\hline
\end{tabular}

Table 3: Relationship between Escherichia Coli and E.Coli 0157:H7 Prevalence in the Meat and Faeces Samples Based on Locations $X^{2}=0.3291 \quad$ OR $=0.6033 \quad$ P Value $=0.8047 P<0.05$

The E.coli prevalence according to location, shows that there is no significant difference between the two study areas $(\mathrm{P}<0.05)$. Jos South has a prevalence of 75\%, while Jos North has 46\% E. coli 0157:H7 infection rates of 8(10.8\%) were observed in meat sample compared to $5(10.9 \%)$ for faecal sample. There was not significant difference between the two samples $(\mathrm{P}>0.05)$.

\section{Discussion}

Escherichia coli 0157:H7 serogroup is well-described as human pathogen associated with bloody diarrhea, haemolyticuraemic syndrome which is characterized by acute renal failure! affecting mainly children and the immune compromised which can lead to! death. Illnesses are often attributed to the consumption of contaminated bovine food products, direct animal contact, and bovine manure contamination of vegetables, fruits and drinking water.

Ruminants, particularly cattle, are considered the primary reservoir for E. coli 0157:H7, where the organism typically colonizes the lower gastrointestinal tract and is shed in the faeces. Studies have: shown that up to $30 \%$ of all cattle are asymptomatic carriers of E. coli 0157:H7 (Callaway et al., 2006; Reinstein et al., 2007).

The results of this study indicated that out of the two hundred (200)samples examined, 100 were from raw beef obtained from abattoir and 100 from cattle faeces. Out of the total samples analyzed E. coli was isolated from $120(60 \%)$, out of which 13(10.83\%) were positive for E. coli 0157:H7 (Table 3), with the raw beef having higher E. coli prevalence rate of $74 \%$ while the faeces had lower $E$. coli prevalence rate of $46 \%$. There was a significant difference between them $(\mathrm{p}<0.05)$.

Out of the $74 \%$ positive for $E$. coli from beef;8 (10.82\%) had E. coli0157:H7, while out of $46 \%$ positive for $E$. coli from faeces,5(10.87\%) had E. coli 0157:H7 prevalence rate. However, there was no statistically significant difference between the two samples $(\mathrm{p}>0.05)$ as shown in Table 3 .

This result is consistent with the work of Akanbi et al., (2011), whose study showed higher prevalence rate of $E$. coli $0157-. \mathrm{H7}$ in cattle (beef) with 49.4\%. Similarly, the work of Olatoye (2010) showed high prevalence rate of E. coli 0157:H7 18.4\% from cattle in Bodija abattoir, Ibadan. However, this work is not in agreement with the work of Enabulele and Uraih (2009), whose study showed lower prevalence rate-of E. coli0157:H7 in beef with 6.94\%; it also does not correlate with the work done in Iran by Rahimi et al., (2012), whose study shows 8.2\% prevalence rate in beef samples. The difference in results could be associated with the geographical area where this work was carried out, variation in sample size, seasonal variation, variation in breeds, inter-laboratory variation.

Previous work done in cattle suggests that the prevalence of E. coli 0157:H7 in the faeces correlate with the prevalence on the hide and carcasses of animals at slaughter. This current study also shows that male subjects had higher occurrence of $E$. coli $0157:$ H7 from beef with $12.12 \%$ and faeces with $11.86 \%$ than female counterparts with $6.67 \%$ and $7.67 \%$ respectively as shown in Tables 1 and 2 . Even though the proportion of $E$. coli 0157:H7 was higher in male than in female there were no statistically significant different between them $(p>0.05)$.

Some enteric pathogens were also isolated from the beef samples. At the course of analysis there were Proteusspp, Klebsiellaspp, Enterob acter and Salmonella spp. These bacteria which are potential pathogens reside in the intestinal tract of cattle. It was not surprising therefore to have isolated them from carcasses. Abattoir has been identified as a major link in the transmission of most enteric pathogens to the food chain and cross-contamination of the carcasses with faeces during slaughter, transportation, handling and storage in butcheries as revealed by poor sanitary environmental condition under which the animals are slaughtered and sold to consumers. This contamination stems from the animals being 
slaughtered on the abattoir floor that is not properly disinfected after every kill, with butchers and retailers walking- in between carcasses as they transact their business.

This result indicates poor sanitary environmental condition under which these animals are kept and slaughtered. Therefore, a number of measures need to be put in place to reduce the risks of infection. These include good animal husbandry, pre-skinning decontamination of the animals as well as incorporation of Hazard Analysis and Critical Control Points (HACCP) in the abattoirs and making sure that they do their work. High level of contamination in the abattoir and slabs is connected with lack of portable water and inadequate slaughtering basic facilities used.

Further work needs to be carried out on other small ruminants like sheep, pigs, goat, etc. using a large number of samples to ascertain its significance in our dietary products. The findings from this study have very important public health implication because E. coli 0157:H7 is a highly virulent strain of E. coli that is capable of causing disease and death. Good hygiene is therefore very important both at point of slaughter and in our kitchens.

\section{Recommendation}

The findings of this study revealed a number of measures needed to lessen the risk of transmission of $E$. coli 0157:H7 along the food chain from farm to fork. The practices in the local abattoirs and slabs are not in tandem with best practices worldwide, as such the following recommendations should be observed;

- Measures must be put in place by the government to minimize the risks of infections by incorporation of Hazard Analysis and Critical Control Points (HACCP) in the abattoirs.

- National Agency for food and Drug Administration and control (NAFDAC) and Federal Environmental protection Agency (FEPA) should be informed of the existence of this organism in Nigeria, so as to legislate and take appropriate measures in case of an outbreaks.

- $\quad$ There is a need for food handlers to be educated on good hygienic practices.

- Federal Environmental protection Agency (FEPA) should take necessary measures to control waste disposal especially agricultural waste to reduce the health burden that can arise from food and water sources.

\section{Conclusion}

This study revealed the prevalence rate of Escherichia coli and Escherichia coli 0157:H7 infections from both samples analyzed. From the beef samples, $74(74 \%)$ had E. coli while $8(10.8 \%)$ had E. coli 0157:H7 and from the faecal samples 46 (46\%) had E. coli while 5 (10.87\%) had E. coli 0157:H7.

The: isolation of E. coli and E. coli0157:H7 from dietary products in this study revealed a significant economic and public health risk implications.

Conclusively, it is to be noted that with the low level of sanitary practices observed and lack of adequate informative data on infection outbreak in Nigeria, the organism could spread easily without early detection. Hence, it is important to take seriously the isolation of the organism in our food materials.

\section{References}

i. Akanbi, B.O. Mbah, I.P. and Kerry, P.C. (2011): Prevalence of Escherichia coli 0157:H7 on hides and faeces of ruminants at slaughter in two major abattoirs in Nigeria. Journal of Applied Microbiology 53:336-340.

ii. Bell, C. (2012). Approach to the control of entero-haemorrhagicEscherichia coli (EHEC). International Journal of Food Microbiology. 78:197-216.

iii. Callaway, T.R., Edrington, T.R, Brabban, A.D., Keen, J.E., Anderson, R.C., Rossman, M.L, Engler, M.J., enovese, K.J., Gwartney, B.L., Reagan, J.O., Poole, T.L., Harvey, R.B., Kutter, E.M., and Nisbet, D.J., (2006). Faecal prevalence of Escherichia coli 0157:H7, Salmonella, Listeria and bacteriophage infecting Escherichia coli 0157:H7 in feed lot cattle in the southern plains region of United States. Food borne pathogen disease 3, 234-244.

iv. Centers for Disease Control, (2002). Multi-state outbreak of Escherichia coli 0157:H7 infections associated with eating ground beef-United States. MMWR; 51(29):637-639.

v. Cheesbrough, M.A. (1996). Prevalence and characterization of Escherichia coli 0157:H7 isolates from meat and meat products Medical Laboratory Manual for Tropical Countries. Vol 2. Butter Worth and Company Limited, London 499pp.

vi. Enabulele, S.A. and Uraih, N., (2009). Enterohaemorrhagic Escherichia coli 0157:H7 Prevalence in meat and vegetable sold in Benin city, Nigeria. African Journal of Microbiology Resource Vol. 3 (5) pp. 276-279.

vii. Ferens, W.A. and Hovde, C.J., (2011). Escherichia coli 0157:H7: Animal reservoir and sources of human infection. Food borne pathogens Dis, 8:465-485.

viii. Griffin, P.M. and Tauxe, R. V., (1991). The epidemiology of infections caused by Escherichia coli 0157:H7, other entero-haemorrhagic Escherichia coli and the associated haemolyticuraemic syndrome. Epidemiological Review, 13: $60-98$

ix. Gyles, C.L., (2007). Shiga toxin-producing Escherichia coli an overview. Journal Animal Science,85: E45-E62.

x. Islam, M.A., Modol, A.S., de Boer, E., (2008). Prevalence and genetic Characterization of Shigatoxin-producing Escherichia coli isolates from slaughtered animals in Bangladesh. Applied Environmental Microbiology. 24:5414-5421.

xi. Olatoye, I.O., (2010). The incidence and antibiotics susceptibility of Escherichia coli 0157:H7 from beef in Ibadan Municipal, Nigeria. African Journal Biotechnology. Vol. 9(8) Pp. 1196-1199.

xii. Rangel, J.M. J Sparling, P.H., Crowe, C, Griffin, P.M. and Swerdlow, D.L., (2005). Epidemiology of Escherichia coli 0157:H7 outbreaks, United State, 1982- 2002.Emerging Infectious Diseases, 11; 603-609. 
xiii. Rahimi, E., Kazemeini, H.R. and Salajegheh, M., (2012). Escherichia coli 0157: H7 NM prevalence in raw beef, camel, sheep, goat, and water buffalo meat in Fars and Khuzestan provinces, Iran. Veterinary Research Forum .3(1):13-17.

xiv. Reinstein, S., Fox, J.T., Shi, X. and Nagaraja, T.G., (2007). Prevalence of Escherichia coli 0157:H7 in gallbladders of beef cattle. Applied and EnvironmentalMicrobiology.73:1002-1004.

xv. Solomon, E.B., Yaron, S. and Mathews, K.R., (2002). Transmission of Escherichiacoli 0157:H7 from contaminated manure and irrigation water to lettuce plant tissue and its subsequent internalization. Applied Environmental Microbiology, 68 (1): 397-400.

xvi. Tarr, P.I., Fouser, L.S. and Stapleton, A.E., (1995). Haemolyticuraemic syndrome in a six years old girl after a urinary tract infection with Shiga toxin producing Escherichia coli 0157:H7. N Engl J Med,335;635-685.

xvii. Vernozy-Rozand, C., (1997). Detection of Escherichia coli 0157:H7 and other verocytotoxin-producing E.coli (VTEC) in Food. Journal of Applied Microbiology.82; 537-551.

xviii. Yates, Daniel., David,S., Moore, Daren;S. and Starnes. (2008).The. practice of Statistics, 3rd ed. Ring-Bound, Freeman.P 283. 